\title{
Control of Micronutrients Availability in Soil and Concentration in Rice Grain through Field Water Management
}

\author{
Juan Damian Marques Fong ${ }^{1}$, Tsugiyuki Masunaga ${ }^{1} \&$ Kuniaki Sato $^{1}$ \\ ${ }^{1}$ Faculty of Life and Environmental Science, Shimane University, Matsue, Japan \\ Correspondence: Tsugiyuki Masunaga, Faculty of Life and Environmental Science, Shimane University, 1060 \\ Nishikawatsu, Matsue, Shimane 690-8504, Japan. Tel: 81-852-32-6066. E-mail: masunaga@life.shimane-u.ac.jp
}

\author{
Received: February 9, 2015 Accepted: March 19, 2015 Online Published: April 15, 2015 \\ doi:10.5539/jas.v7n5p163 URL: http://dx.doi.org/10.5539/jas.v7n5p163
}

\begin{abstract}
A pot experiment was conducted under different water managements, namely control (continuous flooding condition), 2,3,4WAH (water was drained at two to four weeks after heading), and FCap (the soil moisture was kept at field capacity level, to maintain aerobic soil condition). We examined the influence of the establishment of aerobic soil condition at different timing of rice post-heading stage. The results showed that water managements changed soil redox potential and $\mathrm{pH}$ that were known to be responsible of micronutrients availability in soil. Transition from flooding condition to aerobic condition during rice post-anthesis stage, reduced $\mathrm{pH}$ toward its initial value as well as Fe availability in soil. Although soil was re-oxidized in 2,3,4WAH treatments, which reduced $\mathrm{Fe}$ availability in soil from the level of control treatment, concentration of $\mathrm{Fe}$ in grain did not differ between control and drained treatments. Correlation analyses exhibited that the reduction of Fe availability in soil under aerobic condition in 2,3,4WAH and FCap enhanced $\mathrm{Zn}$ and $\mathrm{Cu}$ availabilities in soil and increased concentration of $\mathrm{Zn}, \mathrm{Cu}$ and $\mathrm{Mn}$ in grain. The results point up toward that, enhancement of micronutrient availability in soil during post-heading stage are strongly associated with its grain micronutrient concentration. Establishment of aerobic condition from two weeks after heading increased the grain $\mathrm{Zn}, \mathrm{Cu}$ and Mn concentration by 11, 20 and 35 percent respectively over the values in flooding condition, without negative effects on yield parameters. Unlike control and 2,3,4WAH treatments, FCap that kept aerobic soil condition performed high concentration of grain micronutrients but its low yield.
\end{abstract}

Keywords: grain filling stage, micronutrients concentration, soil availability, rice, water management

\section{Introduction}

Micronutrient deficiencies in soil have been identified as one of main factors affecting crop yield, food quality and human health (Yang et al., 2007; Alloway, 2008). In recent years, emphasis on agriculture, environment, demographic growth and micronutrient malnutrition has increasingly taken center stage in policy discussions on food security in developing countries. The inhabitants of these countries are prone to suffer from undernourishment, caused by inadequate food intake or intake of foods of poor nutritional quality (Bain et al., 2013). New approaches have been applied in achieving sustainable improvements in the micronutrient status of vulnerable populations. One of them is the "genetic biofortification" which has been accepted as a cost-effective and sustainable strategy in order to ameliorate the malnutrition (Cakmak, 2008; Meenakshi et al., 2007). The development of new improved crops varieties, through advanced breeding techniques as well as the screening of germplasm, has allowed for identification of varieties with high potential of accumulating micronutrient in edible parts. Some of the major successes have been observed in crops such as wheat, maize, beans, sweet potato, cassava and rice.

Rice (Oryza sativa L.) is the main staple crop for more than half of the world population (FAO, 2013). In spite of its high consumption, the low content of micronutrient in rice required to meet whole dietary elements necessary to keep a balanced diet in humans, calls for concern. Rice as a major cereal therefore has become a priority for current research works. New findings suggest that micronutrients content in rice grain depends not only on genotypic variables, but also on environmental factors, such as the endogenous soil mineral contents, soil properties ( Cakmak, 2008; Sperotto et al., 2013) water management (Dobermann \& Fairhurst, 2000; Liao et al., 2013) and climate conditions (Najafi-Ghiri et al., 2013).

"Agronomic biofortification" through the application of fertilizer (inorganic or organic), modification of 
cultivation systems, soil management and new irrigation strategies have proved effective in enriching micronutrients content in rice grain by controlling the availability of soil micronutrients for plant (White \& Broadley, 2009). Unlike genetic biofortification, the agronomic biofortification has shown to be a short-term approach, more accessible for developing countries which are facing the burden of malnutrition and where the advanced technologies (e.g. plant breeding and genetic engineering) still remain unreachable (Cakmak, 2008).

Since soil micronutrient availability is highly associated with the contents in plant and grain quality; its availability has become the key limitation factor to productivity, stability and sustainability of rice production in many countries such as Australia, China, India and United States (Bell \& Dell, 2008). Studies conducted by Yang et al. (2007) in China, reported that such deficiencies in soil overlapped areas where population exhibits health micronutrients imbalance, affecting more than $40 \%$ of the population. Usually those deficiencies are afforded by the applications of chemical fertilizer (edaphic and foliar) or organic amendment. The application of $\mathrm{Zn}$ fertilizer has had a positive response in wheat (Triticum aestivum L.), (Cakmak, 2008), sorghum (Sorghum bicolor L.) and rice (Gao et al., 2012). Iron is another important micronutrient for plant and human health. Major Fe deficiencies have been reported mainly in sandy and calcareous soils (Brady \& Weil, 2014). However, under such condition application of inorganic Fe fertilizer often results in ineffective practice due the conversion to ferric form (Rengel et al., 1999). Besides that, the micronutrients content in grain could be controlled by genetic factor meaning that the application of fertilizer even in excess could not increase the content in grain and would rather trigger toxicity symptoms. Likewise micronutrient demand for physiological processes and plant uptake rates could also vary in function of different growing stages and environmental condition (Maschner, 2012).

Rice as well as other crops needs essential micronutrients in very small amount compared to macronutrient. Almost all the soil contains enough micronutrients to support the plants growth demands, however, micronutrients availability often is governed by some soil properties (White \& Broadley, 2009). For example, changes in soil redox potential and $\mathrm{pH}$ are the most important properties that could affect micronutrient availability in paddy (Tao et al., 2007; Brady \& Weil, 2014). Likewise, soil organic matter and its decomposition processes have a significant and direct impact on the availability of micronutrients (Marschner \& Rengel, 2007). Other factors such as synergistic and antagonist interactions among micronutrients and essential elements could also often affect micronutrient uptake by crops (Fageira, 2002).

In order to increase the contents of micronutrients in grain, understanding the dynamics of micronutrient at different growing stages is also very important. Some studies have pointed out that the period between panicle initiation to maturity is considered as high demand for grain micronutrient accumulation. For instance, concerning $\mathrm{Zn}$ uptake, Jiang et al. (2007) reported that $36 \%$ of total $\mathrm{Zn}$ in rice grain was taken up directly from soil between anthesis and maturity stages, similar patterns has been described in wheat during grain filling stage (Pearson \& Rengel, 1994). For Fe, as Inoue et al. (2009) observed, Fe-trasnporter gene OsYSL15 was highly expressed during the anthesis and seed formation stage, these stages probably are the active Fe uptake period of rice. Copper $(\mathrm{Cu})$ on the other hand is essential in flower fecundation (Dobermann \& Fairhurst, 2000). Therefore, its demand should significantly increase at anthesis.

With regards to above factors influencing the micronutrient availability in soil, plant uptake and the content in rice grain, little information is available about the effect of water management over micronutrient concentration in grain during grain filling stage. Since changes in soil water condition are strongly associated with micronutrient availability and plant uptake; shifting soil water condition could be a suitable approach to control soil micronutrient availability and to improve the nutritional value of rice in developing countries where farmers do not have easy accesses to fertilizers or other costly approaches. Therefore, the aim of this present study was to assess the effect of water management on the micronutrient contents in rice grain and availability of soil at grain filling stage.

\section{Materials and Methods}

The effects of water management on soil properties and micronutrients content in rice grain, were evaluated through a pot experiment conducted in a greenhouse at Shimane University $\left(35^{\circ} 29^{\prime} \mathrm{N} 133^{\circ} 04^{\prime} \mathrm{E}\right)$, from 2011-2012 during rice growing season in Japan (May 15th/Oct 15th). Plastic bucket ( $\varnothing=24 \mathrm{~cm} \times 25 \mathrm{~cm}$ height) were filled with $7.5 \mathrm{~kg}$ of air dry "Gray Lowland" soil Typic Fluvaquent (USDA, 2010). The general soil characteristics are presented in Table 1. The semi-dwarf (cv. Koshihikari) rice variety was used in this study.

\subsection{Experimental Design}

The pot experiment was laid out in a randomized block design of five water irrigation treatments (Figure 1) with four replications. Control was flooded from transplanting to harvest. The heading stage $(50 \%$ of the panicle exertion) was the benchmark for the next customized irrigation treatments where flooded-irrigation was stopped 
during the post-heading at four week after heading "4WAH," three week after heading "3WAH," and two weeks after heading " $2 \mathrm{WAH}$," and kept in a soil level approximately $35 \pm 3 \%(\mathrm{v} / \mathrm{v})$ moisture, equivalent to $\pm 80 \%$ of its field capacity level. The last treatment was kept at the same moisture condition, $80 \%$ of field capacity conditions "FCap" throughout growth period in order to mimic the conditions of upland systems. Treatments under flooding condition were $\pm 5 \mathrm{~cm}$ water depth. Distilled water was used for irrigation to avoid micronutrient supply through it. Chemical fertilizer (N:P:K) at doses of 45:65:60 kg ha ${ }^{-1}$ respectively was applied based on crop demand as follows: $\mathrm{N}$ was split in four application, $1^{\text {st }}-20 \%$ basal, $2^{\text {nd }}-30 \%$ at tillering stage, $3^{\text {rd }}-40 \%$ at panicle initiation and $4^{\text {th }}-10 \% 15$ days after panicle initiation (PI). P was applied $100 \%$ of dose basal. $\mathrm{K}$ was split in two application $50 \%$ basal and $50 \%$ at panicle initiation.

Table 1. Physical-chemical properties of Typic fluvaquent soil "Gray lowland" collected at paddy field in Shimane prefecture, Japan

\begin{tabular}{ll}
\hline Soil characteristics & Value \\
\hline Sand (\%) & 22.8 \\
Silt $(\%)$ & 37.8 \\
Clay (\%) & 39.4 \\
$\mathrm{pH}$ & 4.85 \\
$\mathrm{EC}\left(\mathrm{mSm}^{-1}\right)$ & 3.87 \\
Bulk Density $\left(\mathrm{g} \mathrm{cm}^{-3}\right)$ & 1.39 \\
Total C $\left(\mathrm{g} \mathrm{kg}^{-1}\right)$ & 17.6 \\
Total N $\left(\mathrm{g} \mathrm{kg}^{-1}\right)$ & 1.6 \\
$\mathrm{NH}_{4}-\mathrm{N}\left(\mathrm{mg} \mathrm{kg}^{-1}\right)$ & 4.91 \\
$\mathrm{NO}_{3}-\mathrm{N}\left(\mathrm{mg} \mathrm{kg}^{-1}\right)$ & 8.22 \\
Available P $\left(\mathrm{mg} \mathrm{kg}^{-1}\right)$ & 34.9 \\
\hline
\end{tabular}

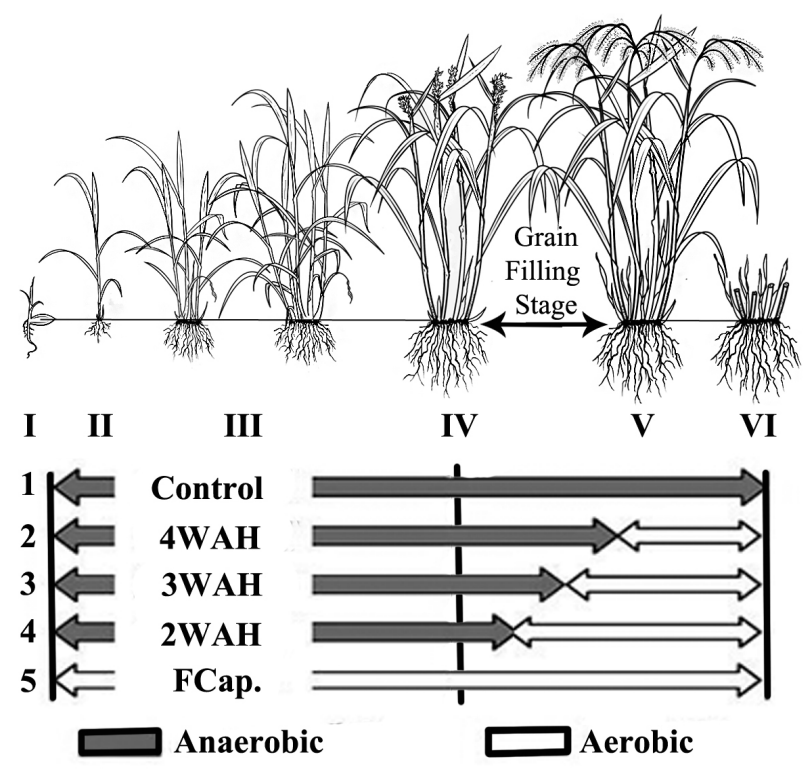

Figure 1. Schematic representation of randomized block design at with different irrigation treatments were applied during the growth season. (I) Sowing, (II) Transplanting, (III) Tillering, (IV) Heading, (V) Maturity Stage, (VI) Harvest. Period between $(\leftrightarrow)$ IV and V was considered as grain filling stage 


\subsection{Plant and Rice Grain Chemical Analysis}

Plant samples were collected at harvest. Flag leaves were first washed with tap water and twice with distilled water. Thereafter they were oven dried at $40{ }^{\circ} \mathrm{C}$ for 48 hours and dehusked in rotating rubber roll, (Satake THU35B, Japan). For micronutrient analysis, flag leaves and grain samples were ground into fine powder in agate grinding jars, using a mixer mill (MM200, Retsch GmbH, Haan, Germany). Grain and plant samples were oven-dried 12 hours at $80^{\circ} \mathrm{C}$. Subsequently $0.5 \mathrm{~g}$ of sample was digested in $2.5 \mathrm{ml} \mathrm{HNO}$ within Teflon vessel. All samples were oven heated at $160^{\circ} \mathrm{C}$ for 4 hours, kept resting overnight and diluted with distilled water up to $25 \mathrm{ml}$ (Koyama \& Sutoh, 1987). The concentrations of $\mathrm{Fe}, \mathrm{Zn}, \mathrm{Cu}$ and $\mathrm{Mn}$ were determined by Inductive Coupled Plasma Spectroscopy (ICPE-9000, Shimadzu, Japan).

\subsection{Soil Sampling and Analysis}

Soil samples were collected from 5, 10 and $15 \mathrm{~cm}$ depth in the bucket after harvest. They were immediately stored in ZIPLOC hermetic plastic bag and refrigerated in order to maintain original chemical soil properties. Portions of each sample was oven dried at $105{ }^{\circ} \mathrm{C}$ to measure the moisture content to calculate the necessary amount for all the subsequent analyses following standard analyses methods (Japan Soil Environment Analysis Methods Committee, 2003). The concentration of micronutrients (Fe, $\mathrm{Zn}, \mathrm{Cu}$ and $\mathrm{Mn}$ was analyzed by mixing 10 $\mathrm{g}$ of soil with $20 \mathrm{ml}$ of diethylene triamine pentaacetic acid (DTPA-TEA) extracting solution (Linsay \& Norvel, 1978). The solution obtained was filtered and analyzed in ICPE-9000. Soil $\mathrm{pH}$ was determined by the soil-water ratio of 1:2.5 and electric conductivity (EC) soil-water ratio of 1:5 using electrode method (D-24 HORIBA, Japan). Redox potential was measured in situ from transplanting period to 25 DAT at $10 \mathrm{~cm}$ depth using electrode method (PNR-41, DKK-TOA Co., Japan).

\subsection{Statistical Analysis}

To determine the influence of water management on soil properties, micronutrient concentration in soil, plant and rice grain accumulation, data were statistically analyzed by one-way analysis of variance (ANOVA). Significant differences among the treatments were determined by Turkey's honestly significant difference (HSD) test $(\mathrm{P}<0.05)$ for multiple means comparison. Correlation analysis between grain micronutrient concentration and soil properties was done using Pearson Product Moment Correlation (PPMC). All statistical analysis was performed using IBM SPSS Statistic v20.0 (IBM SPSS, 2011. Chicago IL, USA).

\section{Results}

\subsection{Soil Properties}

Effects of flooding on soil redox potential (Eh) (Figure 2a) were observed from transplanting until early tillering stage (25 DAT). There was a sharp decrease over time in the $E h$ at the $10 \mathrm{~cm}$ depth, from +467 to $-379 \mathrm{mVolt}$ $(\mathrm{mV})$. This suggested that depletion of $\mathrm{O}_{2}$ and an increase in electron activity mediated by microorganisms respiration was highly marked in the first five days. However, after 17 days Eh values achieved an apparent stability, without significant changes. As a result of changes in the soil electrical conductivity in the flooded treatments, the $\mathrm{pH}$ increased from initial $\mathrm{pH} 4.85$ (transversal dashed line) at transplanting (Figure 2b). In the control which was flooded throughout the growth stage, $\mathrm{pH}$ was 6.18 at the harvest stage, significantly higher than that of the other treatments that were drained after heading at 4, 3, 2 WAH. In the drained treatments, $\mathrm{pH}$ ranges declined between 5.54-5.58 without significant differences among them. Results show that $\mathrm{pH}$ acquires specific values at specific soil moisture. FCap treatment showed the lower $\mathrm{pH}$ of 5.24. 

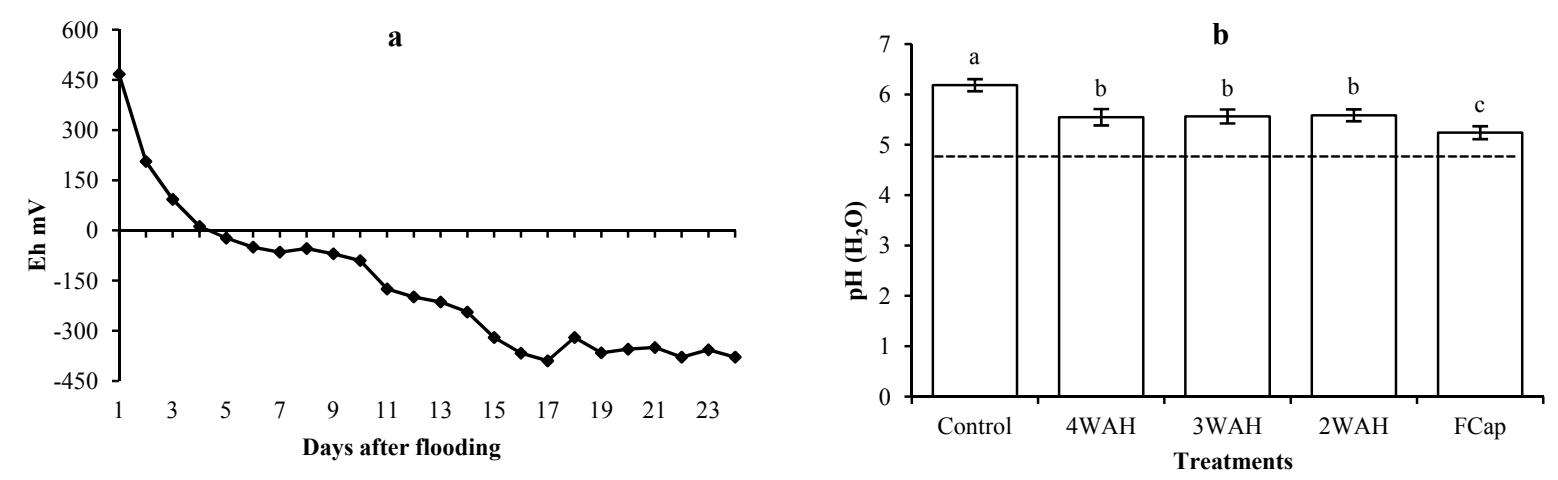

Figure 2. Influence of soil flooding on soil electrochemical properties. a) Soil Redox Potential; b) Soil $\mathrm{pH}\left(\mathrm{H}_{2} \mathrm{O}\right)$. [dashed line represent the pre-flood $\mathrm{pH}$ value]

\subsection{Influence of Water Management on Grain Micronutrient Contents and Yield}

One-way analysis of variance (ANOVA) showed that, there were statistically significant differences between means of micronutrient concentration in grain $(\mathrm{P}$-value $<0.05)$ Table 2 . Therefore resulted in rejection of the null hypothesis which stated that all the data came from groups with the same mean. In this case, subsequent analysis will help us to find a significant difference between pairs of means in at least one of the treatments.

Table 2. One-Way analysis of variance (ANOVA) for the concentration of micronutrients in grain

\begin{tabular}{|c|c|c|c|c|c|c|}
\hline & & Sum of Squares & df & Mean Square & $\mathrm{F}$ & Sig. \\
\hline \multirow[t]{3}{*}{ Grain-Fe Concentration } & Between Groups & 139.438 & 4 & 34.860 & 9.888 & 0.000 \\
\hline & Within Groups & 123.385 & 35 & 3.525 & & \\
\hline & Total & 262.824 & 39 & & & \\
\hline \multirow[t]{3}{*}{ Grain-Zn Concentration } & Between Groups & 204.186 & 4 & 51.046 & 11.431 & 0.000 \\
\hline & Within Groups & 156.292 & 35 & 4.465 & & \\
\hline & Total & 360.477 & 39 & & & \\
\hline \multirow[t]{3}{*}{ Grain-Cu Concentration } & Between Groups & 36.593 & 4 & 9.148 & 17.769 & 0.000 \\
\hline & Within Groups & 18.020 & 35 & 0.515 & & \\
\hline & Total & 54.613 & 39 & & & \\
\hline \multirow[t]{3}{*}{ Grain-Mn Concentration } & Between Groups & 3043.854 & 4 & 760.963 & 16.706 & 0.000 \\
\hline & Within Groups & 1594.257 & 35 & 45.550 & & \\
\hline & Total & 4638.111 & 39 & & & \\
\hline
\end{tabular}

The concentration of micronutrients in rice grain (Figure 3) differed significantly among irrigation treatments. The Fe concentration in grain ranged from $19.01 \mathrm{mg} \mathrm{kg}^{-1}$ to $13.95 \mathrm{mg} \mathrm{kg}^{-1}$. 4WAH, Control and 2WAH showed the higher Fe concentration with no large significant differences, while 3WAH and FCap were 10\% and 23\% respecctively lower than Control. In contrast to $\mathrm{Fe}, \mathrm{Zn}$ concentration in rice grain was more sensitive to changes in water management (Figure 3b). Treatments FCap and $2 \mathrm{WAH}$ showed values $35.40 \mathrm{mg} \mathrm{kg}^{-1}$ and $33.70 \mathrm{mg} \mathrm{kg}^{-1}$ respectively, representing $18 \%$ and $11 \%$ significantly higher than Control.

The concentration of $\mathrm{Cu}$ in grain clearly rose due the establishment of aerobic condition (Figure 3c). Treatments FCap and 2WAH showed higher concentrations of 4.82 and $4.11 \mathrm{mg} \mathrm{kg}^{-1}$ respectively without significant difference between them. Both treatments almost doubled their concentration in comparison with Control, $4 \mathrm{WAH}$ and 3WAH which were not significantly different. The trend observed for Mn grain concentration was not as we expected for the different water treatments. As soil anaerobic conditions were more prolonged, grain Mn concentration decreased. Values varied from $31.52 \mathrm{mg} \mathrm{kg}^{-1}$ to $55.68 \mathrm{mg} \mathrm{kg}^{-1}$, treatments $2 \mathrm{WAH}$ and FCap rose their Mn concentration by $65-76 \%$ respectively higher than Control (Figure 3d). 

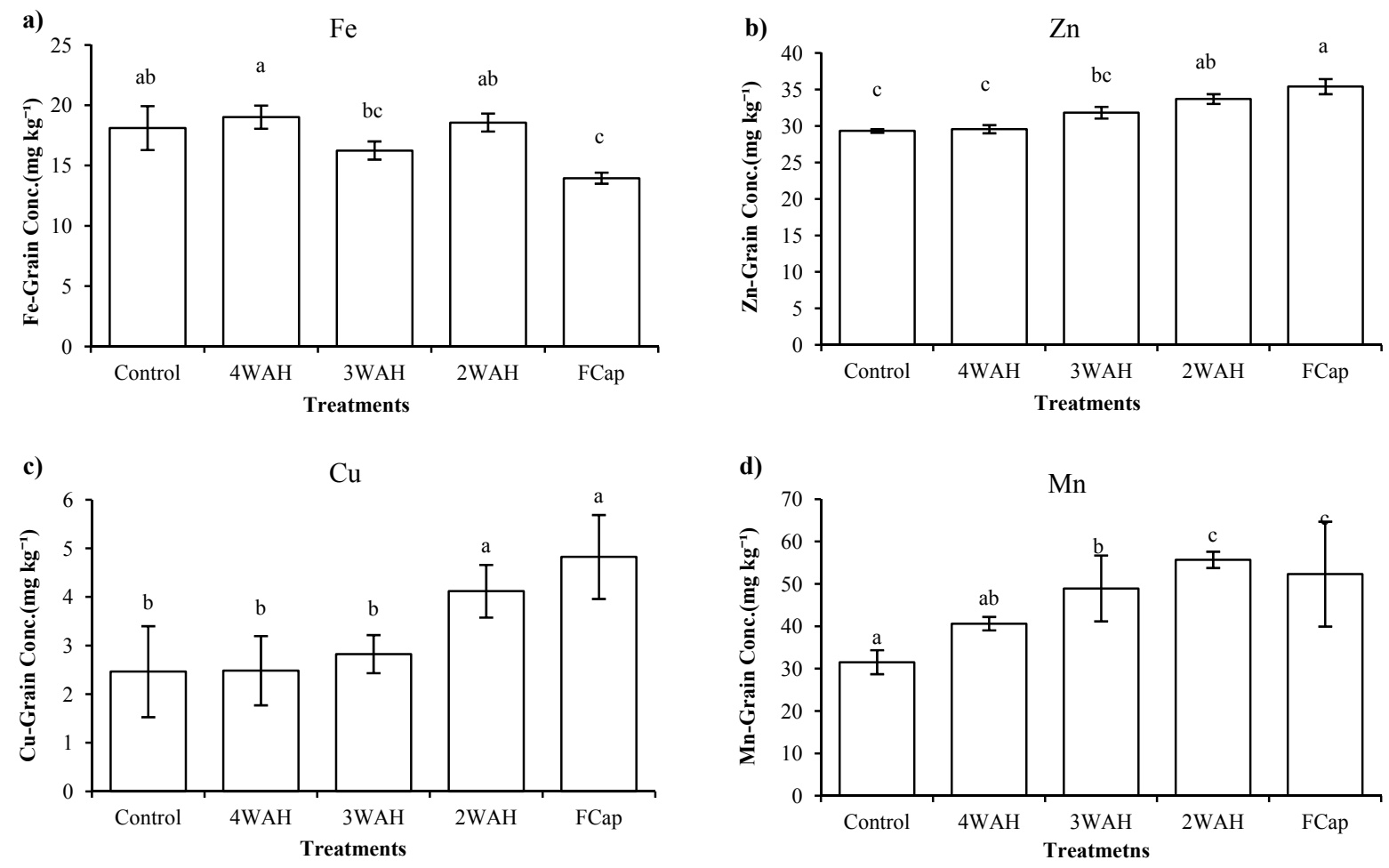

Figure 3. Concentration of micronutrients $(\mathrm{Fe}, \mathrm{Zn}, \mathrm{Cu}$ and $\mathrm{Mn})$ in rice grain, influenced by water management

The effects of soil drainage on grain micronutrient concentration during early grain filling stage, around 75-80 DAT, was beneficial particularly from treatment $2 \mathrm{WAH}$ where the period of flooding was the shortest. That period was identified as high demand for micronutrient acquisition and accumulation. Despite of changes in soil properties, the transition from flooded to aerobic conditions increased grain yield and root density by $7 \%$ and 7.3 $\%$ respectively compared to the control (Table 3 ). Although aboveground plant biomass (leaf and stem weight) showed higher values for drained treatments, we observed that the increase was due the emergence of some new shoots after of the aerobic conditions were established. These tillers did not produce panicle at the time of harvest.

Table 3. Comparison of dry matter weight among different water managements. Values represent means of dry matter weight, on each part of the rice plant

\begin{tabular}{llllll}
\hline & Control & $4 \mathrm{WAH}$ & $3 \mathrm{WAH}$ & $2 \mathrm{WAH}$ & FCap. \\
\hline Grain yield $\left(\mathrm{g} \mathrm{plant}^{-1}\right)$ & $30.1^{\mathrm{b}}$ & $30.5^{\mathrm{ab}}$ & $31.3^{\mathrm{ab}}$ & $32.2^{\mathrm{a}}$ & $15.7^{\mathrm{c}}$ \\
Leaf \& Stems weight $\left(\mathrm{g} \mathrm{plant}^{-1}\right)$ & $101.0^{\mathrm{b}}$ & $108.6^{\mathrm{ab}}$ & $115.9^{\mathrm{a}}$ & $119.4^{\mathrm{a}}$ & $72.0^{\mathrm{c}}$ \\
Roots weight $\left(\mathrm{g} \mathrm{plant}^{-1}\right)$ & $13.7^{\mathrm{a}}$ & $12.9^{\mathrm{ab}}$ & $13.9^{\mathrm{a}}$ & $14.7^{\mathrm{a}}$ & $12.5^{\mathrm{b}}$ \\
\hline
\end{tabular}

Note. * Means followed by different lowercase letter represent the significant difference at $\mathrm{P}<0.05$ among treatments.

\subsection{Soil Micronutrient Availability and Water Management}

Soil micronutrient availabilities were clearly influenced by water managements. The Fe availability (Figure 4a) significantly decreased from Control to FCap. The decreasing change was more evident after the re-oxidation of treatments 4, 3, 2 WAH where the concentration was reduced by more than $20 \%$. Treatments $3 \mathrm{WAH}, 2 \mathrm{WAH}$ and FCap showed a slight increase in $\mathrm{Zn}$ availability by 6,11 and $12 \%$ over Control, respectively, although differences were not statistically significant (Figure 4b). 

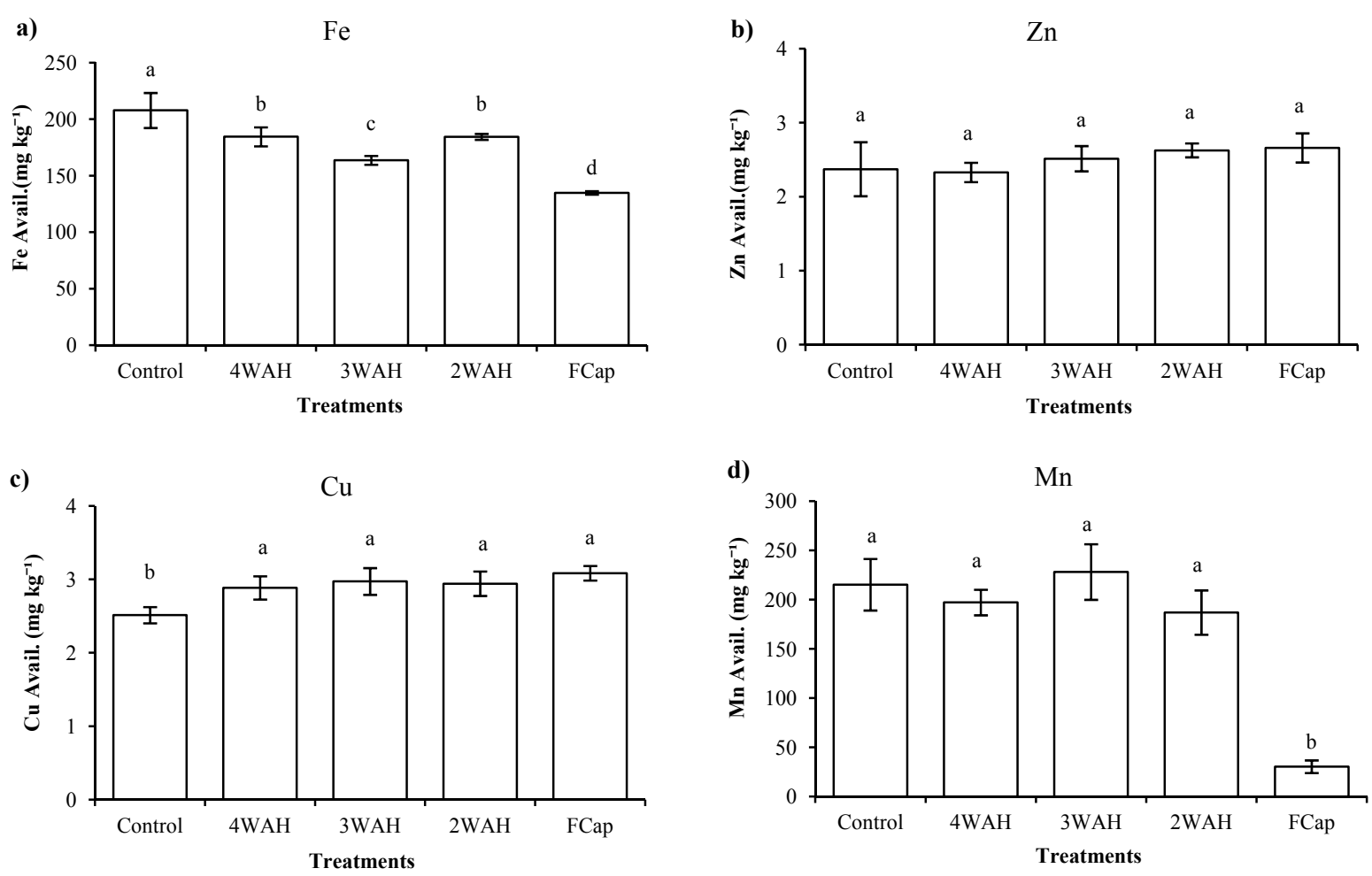

Figure 4. Micronutrients availability ( $\mathrm{Fe}, \mathrm{Zn}, \mathrm{Cu}$ and $\mathrm{Mn})$ in soil

$\mathrm{Cu}$ availability increased sharply as aerobic condition were established. Figure $4 \mathrm{c}$ shows how $\mathrm{Cu}$ availability increase from flooded condition to $4 \mathrm{WAH}$ in a short time. $\mathrm{Cu}$ availability reached its peak values as result of decreasing $\mathrm{pH}$ which is maintained across subsequent treatments. Availability of $\mathrm{Cu}$ did not show significant difference between the drained $(4,3,2 \mathrm{WAH})$ and FCap treatments. FCap and $2 \mathrm{WAH}$ were $>20 \%$ significantly higher than Control. Likewise, Mn availability (Figure 4d) remained high across all the treatments regardless of flooding schedule. These treatments did not showed significant differences among them. Availability of Mn range from $187 \mathrm{mg} \mathrm{kg}^{-1}$ to $228 \mathrm{mg} \mathrm{kg}^{-1}$. Control was six fold higher in available Mn than FCap.

\section{Discussion}

At first, for better understanding of the results of present study, we simply summarize the effect of Soil Eh and $\mathrm{pH}$ change with water management on micronutrient availability in soil. Soil flooding conditions caused modifications in soil $\mathrm{pH}$ and Eh. After its establishment, soil pores were water saturated and Eh started to decrease progressively (Figure 2a). The depletion of $\mathrm{O}_{2}$, triggered new processes driven mainly by strict facultative anaerobic microbes that thrive under these environments. They take over further biochemical reactions, using substances other than $\mathrm{O}_{2}$ as the terminal electron acceptor to metabolize organic compounds (Berkowitz, 2014). In the present study, the $\mathrm{pH}$ increase under flooding condition (Figure 2b), could be led by Eh reduction and the hydrogen consumption, during the reduction process of $\mathrm{MnO}_{2}$ and $\mathrm{Fe}(\mathrm{OH})_{3}$ and other transition elements demanded in microbes metabolism (Brady \& Weil, 2014). The transition from flooding to aerobic condition during grain filling stage, reduced $\mathrm{pH}$ suggesting that establishment of aerobic condition could have affected the Eh and therefore $\mathrm{pH}$ could be progressively restored toward its initial value, as soil is re-oxidized (Zhou et al., 2014). Redox reactions (i.e. gain and losses of electrons) can define both the soil $\mathrm{pH}$ and the availability of micronutrients (White \& Broadley, 2009).

\subsection{Fe Dynamics}

In our result, $\mathrm{Fe}$ availability (Figure $4 \mathrm{a}$ ) was over the critical level in soil $\left(5 \mathrm{mg} \mathrm{kg}^{-1}\right)$ for deficiency and below $300 \mathrm{mg} \mathrm{kg}^{-1}$ in leaf for toxicity (Dobermann \& Fairhurst, 2000). The availability of Fe in soil was significantly higher in flooded than drained treatments, which implies that $\mathrm{Fe}$ availability in soil depends on soil Eh. Therefore water management becomes the major controlling factor to consider in promoting Fe plant uptake. Results also showed that even when soil became aerobic, Fe availability decreased at 2, 3 and 4WAH, but the grain $\mathrm{Fe}$ concentration was kept comparable in all the treatments except FCap. Moreover, transition from 
flooding to aerobic and re-oxidation of $\mathrm{Fe}^{2+}$ to less soluble form at $2 \mathrm{WAH}$ and the other drained treatments, did not affect substantially the concentration of $\mathrm{Fe}$ in grain. Remobilization of $\mathrm{Fe}$ from tissues to the grain may explain this phenomena. Studies conducted on rice by Sperotto et al. (2013) suggested that leaves were the main source to supply $\mathrm{Fe}$ to the seeds by remobilization from old tissues. Besides, release of organic acids (phytosiderophores) in rhizosphere might also contribute to $\mathrm{Fe}$ acquisition under aerobic condition and deficiency stress (Nozoye et al., 2013). Rice plant, during the tillering and reproductive stages is able to accumulate Fe as ferritin a "Fe-reserve protein" (Da Silveira et al., 2009). This Fe is remobilized via phloem by metal-transporters such as OsIRT1, OsIRT2, OsYSL15, and OsNRAMP5 which enhance their activity during grain filling stage (Bashir et al., 2013). In addition, the enhancement of Fe availability in soil, inhibited the availability of $\mathrm{Zn}$ and $\mathrm{Cu}$ in soil (Dobermann \& Fairhurst, 2000) and the concentration of $\mathrm{Zn}, \mathrm{Cu}$ and $\mathrm{Mn}$ in grain as showed correlation matrix (Table 4) therefore the re-oxidation of Fe to less soluble form from 2WAH, might facilitate the uptake of such micronutrients and improve the concentration in grain

\subsection{Zn Dynamics}

Regarding available $\mathrm{Zn}$ values, in soil were above the critical levels $\left(0.8 \mathrm{mg} \mathrm{kg}^{-1}\right)$ for deficiency (Dobermann \& Fairhurst, 2000). The concentration of $\mathrm{Zn}$ in grain as well as the concentration in soil was the highest in FCap, and also tended to increase by transition from Control, to 2, $3,4 \mathrm{WAH}$ (Figures $3 \mathrm{~b}$ and $4 \mathrm{~b}$ ). These enhancements in grain positively correlated $(\mathrm{P}<0.01$ ) with the $\mathrm{Zn}$ availability in soil (see Table 4). Although $\mathrm{Zn}$ availability in soil might be affected by several factor (Sadeghzadeh, 2013) apparently, the reestablishment of aerobic condition, $\mathrm{pH}$ declining and reduction of $\mathrm{Fe}$ to less available form were the major factor controlling $\mathrm{Zn}$ availability. The timing in which irrigation was stopped, also played an important role for $\mathrm{Zn}$ acquisition. Unlike FCap, which achieved high grain $\mathrm{Zn}$ but low yield, 2WAH showed the best performance in terms of $\mathrm{Zn}$ grain concentration and grain yield (Table 3 ). The period in which soil was re-oxidized coincided with grain filling stage, which has been identified as high demand period not only for the uptake and remobilization of $\mathrm{Zn}$ but also other essential elements (Pearson \& Rengel, 1994; Bashir et al., 2013) Many researchers found that $\mathrm{Zn}$ is translocated from old tissues to flag leaf and afterwards remobilized to the grain (Rengel et al., 1999; Wu et al., 2010). However, the higher percentage of $\mathrm{Zn}$ moved into the grain is taken up directly by root, during post-heading stage (Jiang et al., 2007; Sperotto et al., 2013). Although the availability in soil did not show significant differences with control, $2 \mathrm{WAH}$ responded more positively than other treatments. In comparison with $2 \mathrm{WAH}$, treatments 3 and $4 \mathrm{WAH}$ did not increase their $\mathrm{Zn}$ grain concentration even when aerobic condition could have facilitated availability of $\mathrm{Zn}$. Under flooding condition, $\mathrm{Zn}$ can be precipitated as $\mathrm{ZnS}$ and $\mathrm{Zn}(\mathrm{OH})_{2}$ or reduced its transport and root uptake by $\mathrm{HCO}_{3}$ which is the predominant anion at such condition (Dobermann \& Fairhurst, 2000). The small enhancement in root density (Table 3 ) observed in $2 \mathrm{WAH}$, also could be another positive factor that facilitated a larger soil contact area (Yang et al., 2004) and therefore, increase $\mathrm{Zn}$ uptake by plant.

\subsection{Cu Dynamics}

Available $\mathrm{Cu}$ in soil is held mainly as a free cupric ion $\left(\mathrm{Cu}^{2+}\right)$ which is the preferred form for plant (Hoang et al., 2008). In our results the $\mathrm{Cu}$ behavior in soil and grain was broadly similar with the trend observed in $\mathrm{Zn}$. Results showed that the water condition at this period in which soil was re-oxidized at early grain filling stage, i.e. two weeks after heading, was determining factor controling the $\mathrm{Cu}$ contents in grain. Figures $3 \mathrm{c}$ and $4 \mathrm{c}$, showed a close relationship between soil $\mathrm{Cu}$ availability and grain concentration. Furthermore, the shifting from anaerobic to aerobic condition promote enhancement of $\mathrm{Cu}$ solubility and bioavailability as well as better root uptake (Liao et al., 2013). On the other hand the lower $\mathrm{Cu}$ availability observed in treatments where anaerobic condition was kept longer, could be ascribed to the formation of Cu-ferrite $\left(\mathrm{Cu}_{2} \mathrm{Fe}_{2} \mathrm{O}_{4}\right)$, organic matter bound and formation of insoluble CuS (Dobermann \& Fairhurst, 2000). Soil Zn availability did not significantly increase when the aerobic conditions were established, but $\mathrm{Cu}$ did (Figures $4 \mathrm{~b}$ and $4 \mathrm{c}$ ). This suggested that $\mathrm{Cu}$ is able to increase in availability easier than did $\mathrm{Zn}$. Garnett et al. (2005) reported that more than $60 \%$ of $\mathrm{Cu}$ in grain was absorbed at filling stage, which explains the importance of timing in water management to increase grain $\mathrm{Cu}$ concentration. Enhancement of $\mathrm{Cu}$ availability is advisable in soils where $\mathrm{Cu}$ do not exceed toxic level for plant and humans (Xu et al., 2006).

\subsection{Mn Dynamics}

Despite of establishment of aerobic condition, scheduled at 2, $3,4 \mathrm{WAH}$, soil Mn availability remained high (Figure 4d) without significance changes compared with control. Since Mn is reduced at higher potential ( $+400 \sim$ $-100 \mathrm{mV})$ than $\mathrm{Fe}(+200 \sim-200 \mathrm{mV})$ (Kyuma, 1997), the Mn availability in soil can be kept stable longer than Fe in drained treatments of which the moisture condition changed. Although $\mathrm{Fe}$ and $\mathrm{Mn}$ take active parts in redox reactions in soil and both are able to increase their availability after soil flooding, presumably, high Fe 
availability observed in soil, adversely inhibited Mn uptake by roots, because of the antagonist interaction in soil (Dobermann \& Fairhurst, 2000; Millaleo et al., 2010; Das, 2014). Alam (1985) reported that a concentration of $\mathrm{Mn}$ in leaves and stems of 7 weeks plants were increased when Fe application ranged $0-30 \mathrm{mg} \mathrm{kg}^{-1}$ in soil, but above $30 \mathrm{mg} \mathrm{kg}^{-1}$ application reduced Mn concentration in plant. Other studies conducted by Pearson and Rengel, (1994) concluded that $\mathrm{Mn}$ concentration in flag leaf and other active leaves increased during grain filling stage, but remobilization to the grain was not carried out, regardless of the leaf concentration. Suggesting that, continuous uptake from soil seems to be the main source of grain Mn. However its behavior still remains unclear, therefore further investigations are needed to elucidate this issue.

\subsection{Relationship among Soil, Plant and Grain Micronutrients Composition.}

The effect of water management on soil micronutrients availability and its relationship with the concentration in grain and flag leaf are shown in Table 4. The availability of $\mathrm{Fe}, \mathrm{Zn}$ and $\mathrm{Cu}$ in soil significantly correlated with their respective concentrations grain. Soil $\mathrm{pH}$, redox reactions, plant physilogy (Growth stage) and rhyzosphere activity are the main factors controlling the availability in soil and concentration of micronutrients in grain (Dobermann \& Fairhurst, 2000; Gao et al., 2012; Marchner, 2012) mediated by the transition from flooding to aerobic condition. Mn detected in soil did not correlate with $\mathrm{Mn}$ concentration in flag leaf and showed a negative correlation with grain $\mathrm{Mn}(\mathrm{p}<0.05)$. Fe availability in soil correlated negatively with the concentration of $\mathrm{Zn}$ and $\mathrm{Cu}$ in plant and grain $(\mathrm{p}<0.01)$. This observation suggested that availability of $\mathrm{Fe}$ in soil could be attributed to antagonistic interaction, namely inhibition of $\mathrm{Zn}, \mathrm{Cu}$ and $\mathrm{Mn}$ uptake (Dobermann \& Fairhurst, 2000) Negative effects of $\mathrm{Fe}$ excess on $\mathrm{Cu}$ and $\mathrm{Mn}$ shoots concentration have been observed in Indica varieties (Yoshihara et al., 2010). Concentration of $\mathrm{Fe}, \mathrm{Zn}, \mathrm{Cu}$ and $\mathrm{Mn}$ in flag leaf correlated positively with their respective concentration in grain. Moreover, concentration of $\mathrm{Zn}$, and $\mathrm{Cu}$ in grain and flag leaf correlated significantly $(\mathrm{p}<0.01)$ among each other. Studies conducted by Ishimaru et al. (2005) revealed that the expression of ZIP's gene family are actively related with the $\mathrm{Zn}$ and $\mathrm{Cu}$ uptake and transport system. The same mechanism may control the behavior of $\mathrm{Zn}$ and $\mathrm{Cu}$ in plant, which brought the similar results of $\mathrm{Zn}$ and $\mathrm{Cu}$ in the present study.

Table 4. Correlation matrix between soil micronutrients availability and micronutrient concentration in flag leaf and grain

\begin{tabular}{|c|c|c|c|c|c|c|c|c|c|c|c|c|}
\hline & & \multicolumn{4}{|c|}{ Soil Micronutrient } & \multicolumn{4}{|c|}{ Flag leaf Micronutrient } & \multicolumn{3}{|c|}{ Grain } \\
\hline & & $\mathrm{Fe}$ & $\mathrm{Zn}$ & $\mathrm{Cu}$ & $\mathrm{Mn}$ & $\mathrm{Fe}$ & $\mathrm{Zn}$ & $\mathrm{Cu}$ & $\mathrm{Mn}$ & $\mathrm{Fe}$ & $\mathrm{Zn}$ & $\mathrm{Cu}$ \\
\hline \multirow{3}{*}{$\overline{\bar{\circ}}$} & $\mathrm{Zn}$ & $-0.33^{*}$ & & & & & & & & & & \\
\hline & $\mathrm{Cu}$ & $-0.77^{* *}$ & $0.43^{* *}$ & & & & & & & & & \\
\hline & $\mathrm{Mn}$ & $0.71^{* *}$ & $-0.47^{* *}$ & $-0.47^{* *}$ & & & & & & & & \\
\hline \multirow{4}{*}{ 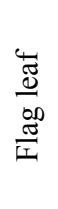 } & $\mathrm{Fe}$ & 0.20 & 0.32 & 0.13 & 0.06 & & & & & & & \\
\hline & $\mathrm{Zn}$ & $-0.68^{* *}$ & 0.41 & 0.38 & $-0.88^{* *}$ & -0.14 & & & & & & \\
\hline & $\mathrm{Cu}$ & $-0.74^{* *}$ & $0.47^{*}$ & $0.61^{* *}$ & $-0.81^{* *}$ & 0.20 & $0.77^{* *}$ & & & & & \\
\hline & $\mathrm{Mn}$ & -0.43 & $0.55^{*}$ & $0.59^{* *}$ & -0.41 & $0.68^{* *}$ & 0.31 & $0.72^{* *}$ & & & & \\
\hline \multirow{4}{*}{. } & $\mathrm{Fe}$ & $0.63^{* *}$ & $-0.38^{*}$ & $-0.41^{* *}$ & $0.55^{* *}$ & 0.31 & $-0.69^{* *}$ & $-0.61^{* *}$ & -0.27 & & & \\
\hline & $\mathrm{Zn}$ & $-0.61^{* *}$ & $0.39^{*}$ & $0.46^{* *}$ & $-0.58^{* *}$ & 0.31 & $0.73^{* *}$ & $0.86^{* *}$ & $0.76^{* *}$ & 0.25 & & \\
\hline & $\mathrm{Cu}$ & $-0.57^{* *}$ & $0.45^{* *}$ & $0.51^{* *}$ & $-0.66^{* *}$ & 0.34 & $0.72^{* *}$ & $0.93^{* *}$ & $0.80^{* *}$ & 0.24 & $0.87^{* *}$ & \\
\hline & $\mathrm{Mn}$ & $-0.53^{* *}$ & $0.48^{* *}$ & $0.59^{* *}$ & $-0.34^{*}$ & $0.46^{*}$ & 0.28 & $0.64^{* *}$ & $0.85^{* *}$ & 0.24 & $0.72^{* *}$ & $0.79^{* *}$ \\
\hline
\end{tabular}

Note. ${ }^{* *}$ and ${ }^{*}$ represent significant correlation at $\mathrm{P}<0.01$ and $\mathrm{P}<0.05$ respectively.

\section{Conclusions}

Soil water management changes the soil Eh and $\mathrm{pH}$, which control the availability of micronutrient in soil and consequently the concentration in rice grain. When those changes occur during grain filling stage, micronutrients such as $\mathrm{Zn}, \mathrm{Cu}$ and $\mathrm{Mn}$ increase their concentration in the grain, likely due the reduction of $\mathrm{pH}$ and their interaction with other soil properties. Although water management did not exerted significant changes on soil $\mathrm{Fe}$ availability, its re-oxidation to less available form, promoted the increase of $\mathrm{Zn}, \mathrm{Cu}$ and $\mathrm{Mn}$ in grain.

Although researchers have been focused to increase the concentration of micronutrient in grain through breeding 
strategies, if soil management in relation to water condition is not applied, those strategies inevitably will fail. Therefore establishment of aerobic condition starting from 2 weeks post-anthesis till maturity by proper water management such as intermittent irrigation, seems to be the most feasible strategy to increase the concentration of micronutrients in rice grain. Furthermore, this technique did not result in grain yield losses.

Our results exhibited the importance of soil environmental managements in realization of the biofortification program. Plant breeding strategies must work alongside agronomic biofortification techniques. In this particular case of rice, the combination between water management and plant breeding could be the most viable option in order to ensure the supply of micronutrients from the soil and overcome malnutrition in vulnerable populations.

\section{Acknowledgements}

This study was supported by Japan Society for the Promotion of Science (Grant-in-Aid Scientific Research No. 24405047). The author is highly grateful to the members of the Pedosphere Eco-Engineering Laboratory, Faculty of Life and Environmental Science, Shimane University.

\section{References}

Alam, S. M. (1985). Effects of iron and manganese on the growth of rice and on the contents of these elements in rice plants. Agronomie. Retrieved January 7, 2015, from https://hal.archives-ouvertes.fr/hal-00884775/document

Alloway, B. J. (2008). Micronutrient deficiencies in global crop Production. Springer Sci., Dordrecht.

Bain, L. E., Awah, P. K., Geraldine, N., Kindong, N. P., Sigal, Y., Bernard, N., \& Tanjeko, A. T. (2013). Malnutrition in Sub - Saharan Africa: Burden, causes and prospects. The Pan African Medical Journal, 15, 120. http://dx.doi.org/10.11604/pamj.2013.15.120.2535

Bashir, K., Takahashi, R., Nakanishi, H., \& Nishizawa, N. K. (2013). The road to micronutrient biofortification of rice: progress and prospects. Frontier Plant Science, 4, 1-7. http://dx.doi.org/10.3389/fpls.2013.00015

Bell, R.W., \& Dell, B. (2008). Micronutrients for Sustainable Food, Feed, Fibre and Bioenergy production. International Fertilizer Industry Association IFA, Paris, France.

Berkowitz, B. (2014). Biologicaly and mediated transformation. In B. Berkowitz, I. Dror, \& B. Yaron (Eds.), Contaminant geochemistry. Interactions and transport in the Subsurface environment (2nd ed., pp. 381-395). Springer.

Brady, N. C., \& Weil, R. R. (2014). The Nature and Properties of Soil (14th ed.). Pearson Education Limited, USA.

Cakmak, I. (2008). Enrichment of cereal grains with zinc: Agronomic or genetic biofortification? Plant Soil, 302, 1-17. http://dx.doi.org/10.1007/s11104-007-9466-3

Da Silveira, V. C., Fadanelli, C., Sperotto, R. A., Stein, R. J., Basso, L. A., Santos, D. S., ... Fett, J. P. (2009). Role of Ferritin in the Rice Tolerance to Iron Overload. Scientia Agricola, 66, 549-555. http://dx.doi.org/10.1590/S0103-90162009000400019

Das, S. K. (2014) Role of Micronutrient in Rice Cultivation and Management Strategy in Organic Agriculture A Reappraisal. Agricultural Sciences, 5, 765-769. http://dx.doi.org/10.4236/as.2014.59080

Dobermann, A., \& Fairhurst, T. (2000). Rice: Nutrient disorders and nutrient management. Singapore and Los Baños: Potash \& Phosphate Institute (PPI), Potash \& Phosphate Institute of Canada (PPIC), and International Rice Research Institute (IRRI), Philipine.

Fageria, N. K. (2002). Influence of micronutrients on dry matter yield and interaction with other nutrients in annual crops. Pesquisa. Agropecuaria Brasileira, $\quad 37, \quad 1765-1772$ http://dx.doi.org/10.1590/S0100-204X2002001200013

Food and Agriculture Organization (FAO). (2013). In feeding the world. FAO Statistical Yearbook. Retrieved January 7, 2015, from http://www.fao.org/docrep/018/i3107e/i3107e.PDF

Gao, X., Hoffland, E., Stomph, T., Grant, C. A., Zou, C., \& Zhang, F. (2012). Improving zinc bioavailability in transition from flooded to aerobic rice: A review. Agronomy for Sustainable Development, 32, 465-478. http://dx. doi.org/10.1007/s13593-011-0053-x

Garnett T. P., \& Graham R. D. (2005). Distribution and Remobilization of Iron and Copper in Wheat. Annals of Botany, 95, 817-826. http://dx.doi.org/10.1093/aob/mci085

Hoang, T. C., Rogevich, E. C., Rand, G. M., Gardinali, P. R., Frakes, R. A., \& Bargar, T. A. (2008). Copper 
desorption in flooded agricultural soils and toxicity to the Florida apple snail (Pomacea paludosa): Implications in Everglades restoration. Environmental Pollution, 199, 338-347. http://dx.doi.org/10.1016/j.envpol.2007.09.024

Inoue, H., Kobayashi, T., Nozoye, T., Takahashi, M., Kakei, Y., Suzuki K., ... Nishizawa, N. K. (2009). Rice OsYSL15 is an iron-regulated iron(III)-deoxymugineic acid transporter expressed in the roots and is essential for iron uptake in early growth of the seedlings. Journal of Biological Chemistry, 284, 3470-3479. http://dx.doi.org/10.1074/jbc.M806042200

Ishimaru, Y., Suzuki, M., Kobayashi, T., Takahashi, M., Nakanishi, H., Mori, S., \& Nishizawa, N. K. (2005). OsZIP4, a novel zinc-regulated zinc transporter in rice. Journal of Experimental Botany, 56, 3207-3214. http://dx.doi.org/10.1093/jxb/eri317

Japan Soil Standard and Measurement Methods Committee. (2003). Japan Soil Standard and Measurement Methods (6th ed.). Hakuyusha, Tokyo, Japan.

Jiang, W., Struik, P. C., Lingna, J., van Keulen, H., Zhao, M., \& Stomph, T. J. (2007). Uptake and distribution of root-applied or foliar applied ${ }^{65} \mathrm{Zn}$ after flowering in aerobic rice. Annals of Applied Biology, 150, 383-391. http://dx.doi.org/10.1111/j.1744-7348.2007.00138.x

Koyama, T., \& Sutoh, M. (1987). Simultaneous multi element determination of soils, plant and animal samples by inductively coupled plasma emission spectrophotometry. Soil Science \& Plant Nutrition, 58, 578-585.

Kyuma, K. (1997). Newest Soil Science. Asakura, Tokyo Japan.

Liao, L., Xu, J., Peng, S., Qiao, Z., \& Gao, X. (2013). Uptake and Bioaccumulation of Heavy Metals in Rice Plants as Affect by Water Saving Irrigation. Retrieved January 7, 2015, from http://maxwellsci.com/print/ajfst/v5-1244-1248.pdf

Lindsay, W. L., \& Norvell, W. A. (1978). Development of DTPA soil test for zinc, iron, manganese and copper. Journal of America Soil Science Society, 42, 421-428.

Marschner, P. ( 2012). Mineral Nutrition of Higher Plants (3rd ed.). Academic Press, CA., USA.

Marschner, P., \& Rengel, Z. (Eds.). (2007). Nutrient Cycling in Terrestrial Ecosystems. Springer Science \& Business Media. Berlin, Heidelberg.

Meenakshi, J., Johnson, N. L., Manyong, V. M., DeGroote, H., Javelosa, J., Yanggen, D. R., ... Meng, E. (2007). How Cost-Effective is Biofortification in Combating Micronutrient Malnutrition? An Ex ante Assessment. World Development, 38, 64-75. http://dx.doi.org/10.1016/j.worlddev.2009.03.014

Millaleo, R., Díaz, M. R., Ivanov, A. G., Mora, M. L., \& Alberdi, M. (2010). Mn as essential and toxic element for plants, accumulation and resistance mechanisms. Journal of Soil Science Plant Nutrition, 10, 476-494 http://dx.doi.org/ 10.4067/S0718-95162010000200008

Najafi-Ghiri, M., Ghasemi-Fasaei, R., \& Farrokhnejad, E. (2013). Factors Affecting Micronutrient Availability in Calcareous Soils of Southern Iran. Arid Land Research and Management, 27, 203-215. http://dx.doi.org/10.1080/15324982.2012.719570

Nozoye, T., Nagasaka, S., Kobayashi, T., Takahashi, M., Sato, Y., Sato, Y., ... Nishizawa, N. K. (2010). Phytosiderophore Efflux Transporters Are Crucial for Iron Acquisition in Graminaceous Plants. Journal of Biological Chemistry, 286, 5446 - 5454. http://dx.doi.org/10.1074/jbc.M110.180026

Pearson, J. N., \& Rengel, Z. (1994). Distribution and remobilization of Zn and Mn during grain development in wheat. Journal of Experimental Botany. Retrieved December 15, 2014, from http://jxb.boxfordjournals.org/content/45/12/1829.full.pdf

Rengel, Z., Batten, G. D., \& Crowley, D. E. (1999). Agronomic approaches for improving the micronutrient density in edible portions of field crops. Field Crops Research, 60, 27-40. http://dx.doi.org/10.1016/S0378-4290(98)00131-2

Sadeghzadeh, B. (2013). A review of zinc nutrition and plant breeding. Journal Soil \& Science Plant Nutrition, 13, 905-927. http://dx.doi.org/10.4067/S0718-95162013005000072

Sperotto, R. A., Ricachenevsky, F. K., Waldow, V. A., Müller, L. H., Dressler, V. L., \& Fett, J. P. (2013). Rice grain $\mathrm{Fe}, \mathrm{Mn}$ and $\mathrm{Zn}$ accumulation: How important are flag leaves and seed number? Plant Soil Environment, 59, 262-266. Retrieved February 28, 2015, from http://www.agriculturejournals.cz/publicFiles/98742.pdf 
Tao, H., Dittert, K., Zhang, L., Lin, S., Römheld, V., \& Sattelmacher, B. (2007). Effects of soil water content on growth, tillering, and manganese uptake of lowland rice grown in the water-saving ground-cover rice-production system (GCRPS). Journal of Plant Nutrition \& Soil Science, 170, 7-13. http://dx.doi.org/10.1002/jpln.200625033

United States Department of Agriculture (USDA). (2010). Keys To Soil Taxonomy (11th ed.). United States Departament of Agriculture. Retrieved February 28, 2015, from http://www.nrcs.usda.gov/Internet/FSE_DOCUMENTS/nrcs142p2_050915.pdf

White, P. J., \& Broadley, M. R. (2009). Biofortification of crops with seven mineral elements often lacking in human diets - iron, zinc, copper, calcium, magnesium, selenium and iodine. Review. New Phytologist., 182, 49-84. http://dx.doi.org/10.1111/j.1469-8137.2008.02738.x

Wu, C., Lu, L., Yang, X., Feng, Y., Wei, Y., Hao, H. L., ... He, Z. (2010). Uptake, translocation, and remobilization of zinc absorbed at different growth stages by rice genotypes of different $\mathrm{Zn}$ densities. Journal of Agriculture \& Food Chemistry, 58, 6767-6773. http://dx.doi.org/10.1021/jf100017e

Xu, J., Yang, L., Wang, Z., Dong, G., Huang, J., \& Wang Y. (2006). Toxicity of copper on rice growth and accumulation of copper in rice grain in copper contaminated soil. Chemosphere, 62, 602-607. http://dx.doi.org/1.1016/j.chemosphere.2005.05.050

Yang, C., M., Yang, L., Yang, Y., \& Ouyang, Z. (2004). Rice root growth and nutrient uptake as influenced by organic manure in continuously and alternately flooded paddy soils. Agricultural Water Management, 70, 67-81. http://dx.doi.org/10.1016/j.agwat.2004.05.003

Yang, X. E., Chen, W. R., \& Feng, Y. (2007). Improving human micronutrient nutrition through biofortification in the soil-plant system: China as a case study. Environmental Geochemistry \& Health, 29, 413-428. http://dx.doi.org/10.1007/s10653-007-9086-0

Yoshihara, T., Shoji, K., Kohno, Y., \& Goto, F. (2010). Cross relationships of Cu, Fe, Zn, Mn, and Cd accumulations in common japonica and Indica rice cultivars in Japan. Environmental and Experimental Botany, 68, 180-187. http://dx.doi.org/10.1016/j.envexpbot.2009.10.006

Zhou, W., Lv, T. F., Chen, Y., Westby, A. P., \& Ren, W. J. (2014). Soil Physicochemical and Biological Properties of Paddy-Upland Rotation: A Review. The Scientific World Journal. http://dx.doi.org/10.1155/2014/856352

\section{Copyrights}

Copyright for this article is retained by the author(s), with first publication rights granted to the journal.

This is an open-access article distributed under the terms and conditions of the Creative Commons Attribution license (http://creativecommons.org/licenses/by/3.0/). 